\title{
The effects of pregnancy and lactation on the activities of trypsin and $\alpha$-chymotrypsin in the rat pancreas
}

\author{
BY B. A. ROLLS, M. J. HENSCHEL AND MAUREEN F. PALMER \\ National Institute for Research in Dairying, Shinfield, Reading RG2 $9 A T$
}

(Received 6 October 1978 - Accepted 6 November 1978)

1. The food intake, pancreas weight and trypsin (EC 3.4.21.4) and $\alpha$-chymotrypsin (EC 3.4.2 I I) activities in the pancreas were measured in rats during pregnancy and lactation and after the young were weaned.

2. All the quantities measured increased significantly during lactation and had returned to their original values by 4 weeks after weaning. Food intake and pancreas weight were highest after the second week of lactation. Total trypsin and $\alpha$-chymotrypsin activity, and the activity per $g$ tissue, fell during pregnancy and rose during lactation, reaching a maximum I week after weaning.

3. From these and other results it is suggested that the hypertrophy and hypersecretion of pregnancy and lactation are initiated by changes in insulin secretion and mediated by the trophic effects of gut hormones, and that differences in the nature and timing of the response may be controlled by nutrient availability.

Pregnancy and lactation are associated with changes in many extra-reproductive organs (Fell, 1977). Work in rodents and in sheep has shown that there are increases in the weight of the heart, kidneys (Souders, 1955), rumen (Weekes, 1972), stomach (Crean \& Rumsey, I97I) and liver (Souders, 1955; Kennedy et al. 1958; Schwenk \& Joachim, I 96I; Leake et al. 1968; Smith, 1975); while in the small intestine there are increases in weight, length, nitrogen content, villus height, mucosal surface area, epithelial cell migration rate and amino acid absorption (Schwenk \& Joachim, 1961; Fell et al. 1963; Craft, 1970; Fell, 1972; Fell et al. 1972; Moon, 1973; Snook, 1974; Cripps \& Williams, 1975; Rolls, 1975). The mechanisms by which these changes are initiated and effected are the subject of much debate.

The food intake of rats increases slightly during pregnancy and markedly during lactation, falling sharply after the pups are weaned (Schwenk \& Joachim, I96I; Crean \& Rumsey, I971; Rolls, 1975; Fell, 1977). The effects of gastrointestinal hypertrophy appear to be that the digestive capacity of the gut is increased without loss of efficiency. For this reason investigation of the digestive functions in pregnancy and lactation may throw light on some of the mechanisms of adaptation. Recent work in this laboratory has shown that in the rat small intestinal mucosa there are increases, slight during pregnancy and considerable during lactation, in the dipeptidases (Rolls, 1975) and in the metabolic enzymes at different sites in the cell (M. F. Palmer \& B. A. Rolls, unpublished results). In this present study we have investigated the changes in trypsin (EC 3.4.2I.4) and $\alpha$-chymotrypsin (EC 3.4.2I . I) that take place in the rat pancreas during pregnancy and lactation, and after weaning. These enzymes, like the dipeptidases, are affected by diet (Snook, 1974) and as the endocrine pancreas is affected by pregnancy and lactation (Green \& Taylor, 1972; Saudek et al. 1975) effects might also be expected in its exocrine function.

\section{MATERIALS AND METHODS}

\section{Chemicals}

Laboratory chemicals were of Analar grade. Enzyme substrates and biochemicals were bought from Sigma (London) Chemical Co., Kingston-upon-Thames KT $27 \mathrm{BH}$.

0007-I 145/79/3232-061 I \$or.00 (c) 1979 The Nutrition Society 


\section{Animals}

Female Norwegian Hooded rats, 3-4 months old and weighing $230-250 \mathrm{~g}$, from the Institute colony were used. Vaginal smears were examined to determine the stage of oestrus so that matings could be timed. The presence of spermatozoa in subsequent smears was taken to indicate impregnation. For pregnant animals, pregnancy was confirmed by inspection of the uterus at the end of the experiment. All rats were allowed unrestricted access to food (Spratts Laboratory Diet I) and water. Food consumptions were measured immediately before sampling.

At weekly intervals during pregnancy and lactation, and after weaning, rats were taken at the same time of day without previous starvation. The pancreas was quickly removed under light diethyl ether anaesthesia, freed of fat and connective tissue, weighed, cooled rapidly and stored at $-20^{\circ}$ until analysis.

\section{Measurement of enzyme activities}

The pancreases were homogenized individually in $0.05 \mathrm{M}$-Tris buffer, $\mathrm{pH} 8 \cdot 2$, containing $0.02 \mathrm{M}$-calcium chloride. Portions were incubated at $37^{\circ}$ with enterokinase $(E C$ 3.4.21.9) extracted from fresh pig duodenal contents (Kunitz, I939). The activities of trypsin and $\alpha$-chymotrypsin were assayed separately using the chromogenic substrates N-benzoyl-Larginine-p-nitroanilide hydrochloride (BANA) and N-benzoyl-L-tyrosine-p-nitroanilide (BTNA) (Erlanger et al. 196I; Henschel, I973). The substrates were dissolved in dimethyl sulphoxide and diluted appropriately for use: BANA with the Tris-calcium buffer and BTNA with equal volumes (separately) of methanol and the buffer. The homogenates and substrates were incubated at $30^{\circ}$ for $\mathrm{I} h$, the reaction was stopped by the addition of acetic acid and the extinction was measured at $4 \mathrm{IO} \mathrm{nm}$ after filtration. The results are expressed as $\mu$ mol substrate hydrolysed per min for the whole organ and per $\mathrm{g}$ tissue.

\section{RESULTS}

The results are given in Table $\mathrm{I}$ and Fig. I. The control group of unmated animals was killed throughout the period of the experiment. However, there were no significant changes with time in any of the quantities measured. The changes in food intake during pregnancy and lactation were similar to those reported previously (Crean \& Rumsey, 1971 ; Cripps \& Williams, 1975; Rolls, 1975). The maximum food intake was at the end of the third week of lactation. There was a slight, insignificant fall in pancreas weight in early pregnancy and the pancreas was heaviest after 2 weeks of lactation. At 2 weeks after weaning, pancreas weight was similar to weights found in control rats.

The enzyme activities, whether total (which was taken to indicate the digestive capacity of the animal) or expressed per $g$ pancreas (which were taken to reflect changes in the tissue) followed the same pattern. There was a fall in activity in the second and third week of pregnancy, significant in one instance, followed by significant rises during lactation. Maximum enzyme content was found at the end of the first week after weaning, and thereafter there was a steady fall. At 5 weeks after weaning the activities were not significantly different from control values. The proportional changes in $\alpha$-chymotrypsin activity were greater than those for trypsin.

\section{DISCUSSION}

In the present study it was found that food intake, pancreas weight and pancreatic proteolytic activity increased strikingly during lactation and returned gradually after weaning to values close to those found before impregnation. This general pattern was similar to changes 
Table I. Effects of pregnancy and lactation on food intake, pancreas weight and pancreatic trypsin (EC 3.4.2 I.4) and $\alpha$-chymotrypsin (EC 3.4.2 I.I) activities in groups of rats

(Results are given as mean values with their standard errors. Activities of enzymes are expressed as $\mu \mathrm{mol}$ substrate hydrolysed $/ 30 \mathrm{~min}$ at $30^{\circ}$ )

Physiological state of rats $\ldots \quad \ldots \quad$ Unmated

Pregnant (weeks)

No. rats/group

Food intake $(\mathrm{g} / \mathrm{d})$

Difference, unmated rats, $P<*$

Pancreas wt $(\mathrm{g})$

Difference, unmated rats, $P<$

Total trypsin activity

Difference, unmated rats, $P<$

Trypsin activity/g pancreas

Difference, unmated rats, $P<$

Total $\alpha$-chymotrypsin activity

Difference, unmated rats, $P<$

$\alpha$-Chymotrypsin activity/g pancreas

Difference, unmated rats, $P<$

Physiological state of rats

No. rats/group

Food intake $(\mathrm{g} / \mathrm{d})$

Difference, unmated rats, $P<*$

Pancreas wt (g)

Difference, unmated rats, $P<$

Total trypsin activity

Difference, unmated rats, $P<$

Trypsin activity/g pancreas

Difference, unmated rats, $P<$

Total $\alpha$-chymotrypsin activity

Difference, unmated rats, $P<$

$\alpha$-Chymotrypsin activity/g pancreas

Difference, unmated rats, $P<$

Physiological state of rats

No. rats/group

Food intake (g/d)

Difference, unmated rats, $P<*$

Pancreas wt $(\mathrm{g})$

Difference, unmated rats, $P<$

Total trypsin activity

Difference, unmated rats, $P<$

Trypsin activity/g pancreas

Difference, unmated rats, $P<$

Total $\alpha$-chymotrypsin activity

Difference, unmated rats, $P<$

$\alpha$-Chymotrypsin activity/g pancreas

Difference, unmated rats, $P<$

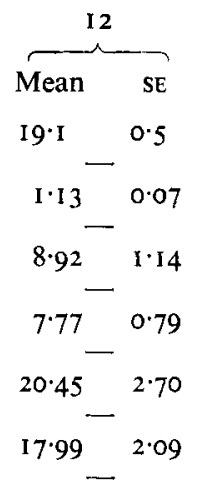

\begin{tabular}{|c|c|c|c|}
\hline 2 & & 3 & \\
\hline 7 & & 7 & \\
\hline Mean & SE & Mean & SE \\
\hline 24.9 & $2 \cdot I$ & $25 \cdot 3$ & $1 \cdot 9$ \\
\hline I. I 6 & 0.03 & $\stackrel{1}{1} \cdot 17$ NS & 0.05 \\
\hline${ }^{6 \cdot 52} \mathrm{NS}$ & 0.88 & ${ }^{6.97} \mathrm{NS}$ & $\mathrm{I} \cdot 33$ \\
\hline${ }^{5.58} \mathrm{NS}$ & 0.71 & ${ }^{5.78}$ NS & 0.88 \\
\hline${ }^{13 \cdot 41} \mathrm{NS}$ & I 87 & ${ }^{14} \cdot 44 \mathrm{NS}$ & $2 \cdot 42$ \\
\hline $\begin{array}{r}\text { II. } 44 \\
0.05\end{array}$ & $1 \cdot 46$ & ${ }^{11} \cdot 94$ & 1.63 \\
\hline
\end{tabular}

Lactating (weeks)

$\overbrace{2}$

\begin{tabular}{|c|c|c|c|c|c|}
\hline \multicolumn{2}{|c|}{7} & \multicolumn{2}{|c|}{7} & \multicolumn{2}{|c|}{9} \\
\hline Mean & SE & Mean & SE & Mean & SE \\
\hline $40 \cdot 2$ & $2 \cdot 2$ & \multirow{2}{*}{\multicolumn{2}{|c|}{$0^{0.3} 0.001 I^{5,1}$}} & $70 \cdot 8$ & $8 \cdot I$ \\
\hline \multicolumn{2}{|c|}{0.001} & & & \multicolumn{2}{|c|}{0.001} \\
\hline $\mathrm{I} \cdot 3 \mathrm{I}$ & 0.05 & $\mathrm{I} \cdot 5 \mathrm{I}$ & 0.05 & I. 38 & 0.06 \\
\hline I $3 \cdot 32$ & $0.8 \mathrm{I}$ & 15.24 & $2 \cdot 65$ & 15.210. & $r \cdot 02$ \\
\hline $10 \cdot 15$ & 0.54 & $10 \cdot 17$ & $1 \cdot 88$ & II 02 & 0.52 \\
\hline $26 \cdot 80$ & $I \cdot 43$ & $31 \cdot 6 I$ & 3.05 & ${ }^{37 \cdot 86} 0$ & ${ }_{1}^{2 \cdot 14}$ \\
\hline 20.43 & NS & $2 \mathrm{I} \cdot 22$ & $2 \cdot 32$ & $27 \cdot 56$ & $I \cdot 32$ \\
\hline
\end{tabular}

Period after weaning (weeks)

\begin{tabular}{|c|c|c|c|c|}
\hline \multicolumn{5}{|c|}{ Period after weaning (weeks) } \\
\hline I & 2 & 3 & 4 & 5 \\
\hline IO & 9 & 6 & 7 & 7 \\
\hline Mean & Mean & Mean & Mean & Mean \\
\hline $\begin{array}{c}28 \cdot 4 \\
0.001\end{array}$ & $\begin{array}{cc}25 \cdot 6 & 1 \cdot 7 \\
0 \cdot 001 & \end{array}$ & $2 \mathrm{I} \cdot 30.6$ & ${ }^{19.9} \mathrm{NS}^{0.6}$ & ${ }^{18 \cdot 7} \mathrm{NS}^{2 \cdot 0}$ \\
\hline $\begin{array}{c}I \cdot 34 \quad 0.07 \\
0.05\end{array}$ & ${ }_{\mathrm{NS}}^{\mathrm{I} \cdot \mathrm{I} 8{ }^{0.06}}$ & ${ }_{\mathrm{NS}}^{1.05} 0.05$ & ${ }_{\mathrm{NS}}^{\mathrm{I} \cdot 08}{ }^{0.06}$ & ${ }_{\mathrm{NS}}^{0.90}{ }^{0.07}$ \\
\hline $\begin{array}{c}16.78 \quad I \cdot 93 \\
\text { O.OI }\end{array}$ & $\begin{array}{c}12.23 \quad 0.97 \\
0.05\end{array}$ & $\begin{array}{c}\text { II } 12 \\
0.05\end{array}$ & $\begin{array}{c}8 \cdot 30 \quad 0 \cdot 69 \\
\text { NS }\end{array}$ & ${ }^{7.00} \mathrm{NS}{ }^{0.72}$ \\
\hline $\begin{array}{c}\mathrm{I} 2.45 \\
0.0 \mathrm{OI}\end{array}$ & $\begin{array}{c}10.33 \\
0.05\end{array}$ & ${ }^{10.64} \mathrm{NS} \quad 0.86$ & ${ }^{7.93}{ }_{\mathrm{NS}}^{0.95}$ & $7.75{ }_{\mathrm{NS}}^{0.43}$ \\
\hline $\begin{array}{c}40.05 \quad 3.72 \\
0.001\end{array}$ & $\begin{array}{c}28.38 \quad 2.45 \\
0.05\end{array}$ & $\mathrm{NS}^{26 \cdot 46}$ & ${ }^{24 \cdot 07}{ }_{\mathrm{NS}}^{\mathrm{I} \cdot 82}$ & $\mathrm{NS}^{20 \cdot 82}$ \\
\hline $\begin{array}{cc}29 \cdot 71 & 1 \cdot 54 \\
0.001 & \end{array}$ & $\begin{array}{c}23 \cdot 87 \quad I \cdot 2 I \\
0.05\end{array}$ & ${ }_{\mathrm{NS}}^{25 \cdot 42}{ }^{3 \cdot 19}$ & ${ }_{\mathrm{NS}}^{22 \cdot 68}{ }^{\mathrm{I} \cdot 84}$ & ${ }_{\mathrm{NS}}{ }^{1 \cdot 6 \mathrm{I}}$ \\
\hline
\end{tabular}

* The significances of the differences of the values from corresponding values for the unmated rats. NS, not significant $(P>0.05)$. 


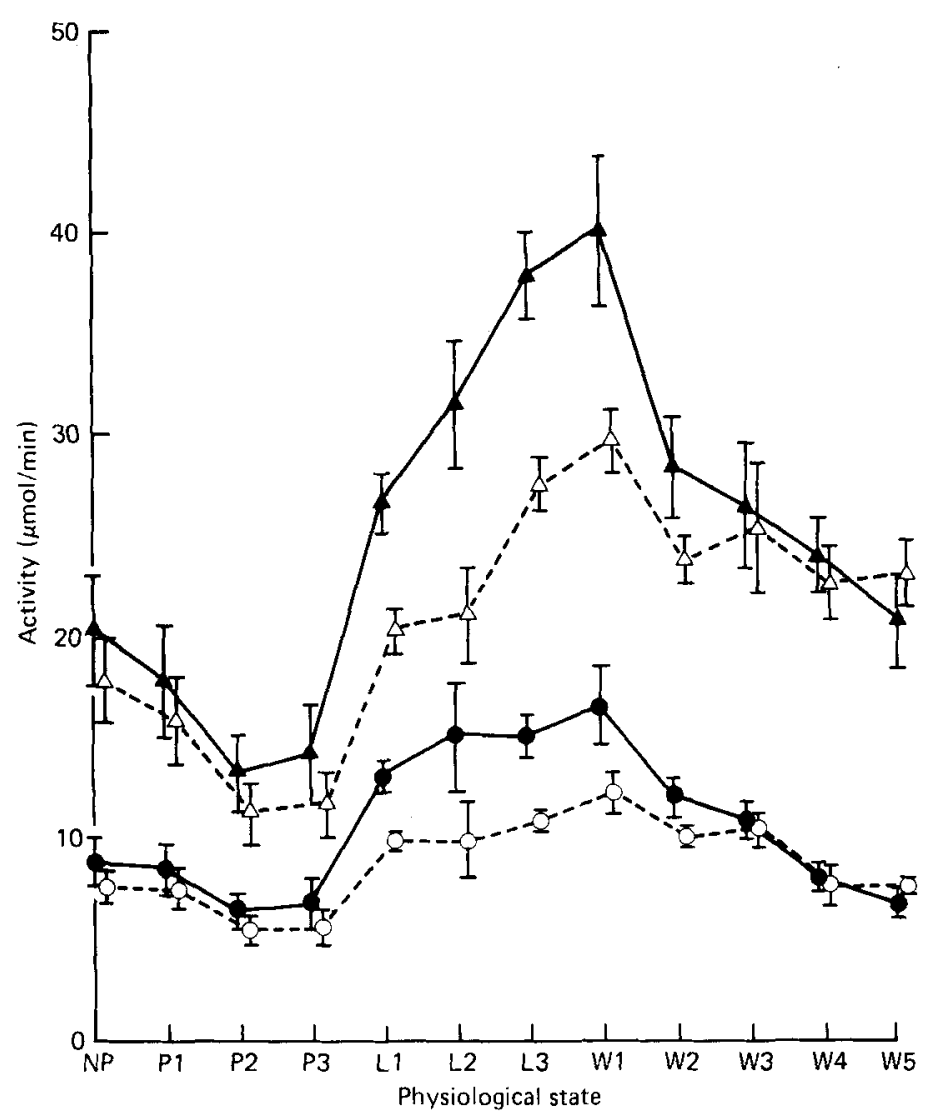

Fig. I. Activities ( $\mu \mathrm{mol}$ substrate hydrolysed $/ \mathrm{min}$ ) in the rat pancreas of total trypsin $(E C$ 3.4 21 . 4; $-0)$, trypsin/g tissue $(\bigcirc--O)$, total $\alpha$-chymotrypsin $(E C 3.4 .21 .1 ; \Delta-\Delta)$ and $\alpha$-chymotrypsin/g tissue $(\triangle--\triangle)$ during pregnancy and lactation and after weaning. Measurements were made on non-pregnant rats (NP); after $I_{,} 2$ and 3 weeks of pregnancy $\left(P_{1}, P_{2}, P_{3}\right)$; after I, 2 , and 3 weeks of lactation $\left(\mathrm{L}_{1}, \mathrm{~L}_{2}, \mathrm{~L}_{3}\right)$ and at $\mathrm{I}_{1}, 2,3,4$ and 5 weeks after the young were weaned $\left(W_{1}, W_{2}, W_{3}, W_{4}, W_{5}\right)$. The vertical bars indicate the standard errors of the observations.

found in small intestinal dipeptidase activity (Rolls, 1975) and metabolic enzymes (M. F. Palmer \& B. A. Rolls, unpublished results) and reported in other extra-reproductive organs (see p. 573). These results are also consistent with the much greater amylase and protein production by the rat pancreas in the second week of lactation, as compared with unmated animals (Barrowman \& Mayston, 1973).

When the present results are considered together with previously published information two apparent inconsistencies emerge. First, pancreatic weight and enzyme activity fall, or fail to rise, during pregnancy and there is a slight fall in liver weight in the first, but not in the second and third week of pregnancy (Schwenk \& Joachim, 1961; Smith, 1975). This fall, or lag, is not seen in the food intake or in the weights and enzyme activities in the intestinal tract (Crean \& Rumsey, 197I; Rolls, 1975). Secondly, the maximum food intake, gastric hypertrophy, intestinal hypertrophy and secretion and pancreas weight occur in mid- or late lactation (Crean \& Rumsey, I97I ; Rolls, 1975; Barrowman \& Mayston, 1973) whereas pancreatic tryptic activity and liver weight are at their highest shortly after weaning, when the demands of lactation are over (Schwenk \& Joachim, 196I; Smith, 1975). 
Any explanation of the changes in extra-reproductive organs during pregnancy and lactation should answer three questions. How is the original stimulus applied, and how is it removed after weaning? How is this stimulus mediated to promote increased food intake, organ hypertrophy and higher enzyme secretion? Why do organ weights and secretions change in different ways and at different times?

We suggest that the original stimulus comes from the reduction in blood glucose and rise in insulin secretion that occurs in pregnancy. The fall in blood glucose may result from the insulin rise or from the demands of the foetuses, since it is abolished by hysterectomy (Scow et al. 1964). Insulin output from pancreatic islets is higher and sensitivity to glucose is greater in pregnant than in non-pregnant rats (Green \& Taylor, 1972) and plasma insulin also rises (Saudek et al. 1975). Gluconeogenesis may be restrained to prevent $N$ loss (Saudek et al. 1975; Smith, 1975). Increased insulin secretion may be a combined effect of placental and maternal hormones since rises in insulin production have been evoked in rats by the administration of human placental lactogen (Malaisse et al. 1969) and by the chronic administration of progesterone and oestradiol (Costrini \& Kalkoff, I971; Hager et al. 1972). A placental stimulus is consistent with the time-scale for hyperplasia of the gastric mucosa (Crean \& Rumsey, 1971) and the fact that increased protein synthesis in the maternal liver depends on the placenta (Campbell et al. I953). Higher food consumption resulting from the action of high insulin and low blood sugar on the hypothalamus would stimulate gastrin secretion via vagal activity and this is known, in turn, to have a trophic effect not only on the stomach and small intestine but also on the pancreas (Mayston \& Barrowman, I97I; Fell, 1972). The increased food intake would also stimulate secretion of most gastrointestinal hormones, which would contribute to the trophic effect. Moreover, gastrin, secretin and cholecystokinin stimulate insulin secretion (Unger et al. 1967) so that food intake would be further increased. It may be noted that the administration of placental hormone to hypophysectomized rats not only increased insulin secretion but also restored the rate of body growth, presumably by stimulating food intake (Malaisse et al. 1969). Food restriction reduces the effect on insulin secretion of pregnancy, although apparently not completely to the unmated state (Green \& Taylor, 1972, 1974), and many of the hypertrophic and secretory effects that can be abolished by food restriction are probably affected by restricted availability of the necessary nutrients.

The fall in pancreatic trypsin and chymotrypsin content and the initial lag in liver and pancreas weight increases that occur despite a slightly increased food intake may be attributed to the demands of the foetoplacental unit, which would have priority of available nutrients. The intestinal tract may not display this effect because of its advantageous physiological position. Once food intake rises sharply, sufficient nutrients would be available for other organs. If the insulin-gastrin effect provides the stimulus, and the food intake the means, for hypertrophy, it is easy to explain why many hypertrophic and secretory effects reach their maximum in mid- or late lactation, together with food intake. It is possible that liver weight and the tryptic activity of the pancreas are less immediately sensitive than other organs to factors promoting a return to the non-breeding state. Since food intake is still markedly above that of unmated rats and the demands of lactation are removed, nutrient availability might permit further hypertrophy during the first week after weaning. One factor involved in the return to the non-breeding state may be a rise in blood glucose.

Whether the hypertrophic effects of pregnancy and lactation are mediated through insulin or, as suggested elsewitere (Elias \& Dowling, 1976), via pancreatic or enteric glucagon, an hormonal stimulus seems more probable than a simple teleological response to food intake, particularly in the instance of the digestive organs, whose reserve capacity is thought to be considerable even in the unmated state.

The authors thank Miss M. Tyler and her staff for their care of the rats. 


\section{REFERENCES}

Barrowman, J. A. \& Mayston, P. D. (1973). J. Physiol., Lond. 229, 4 I $P$.

Campbell, R. M., Innes, I. R. \& Kosterlitz, H. W. (1953). J. Endocr. 9, 52.

Costrini, N. V. \& Kalkoff, R. K. (197I). J. clin. Invest. 50, 992.

Craft, I. L. (1970). Clin. Sci. 38, 287.

Crean, G. P. \& Rumsey, R. D. E. (197I). J. Physiol., Lond. 215, I8I.

Cripps, A. W. \& Williams, V. J. (1975). Br. J. Nutr. 33, 17.

Elias, E. \& Dowling, R. H. (1976). Clin. Sci. mol. Med. 51, 427.

Erlanger, B. F., Kokowsky, N. \& Cohen, W. (196I). Archs Biochem. Biophys. 95, 27 I.

Fell, B. F. (1972). Wld Rev. Nutr. Diet. I4, I80.

Fell, B. F. (1977). Rep. Rowett Inst. 33, 97.

Fell, B. F., Campbell, R. M., Mackie, W. B. \& Weekes, T. E. C. (1972). J. agric. Sci., Camb. $79,397$.

Fell, B. F., Smith, K. A. \& Campbell, R. M (1963). J. Path. Bact. 85, 179.

Green, I. C. \& Taylor, K. W. (I972). J. Endocr. 54, 317.

Green, I. C. \& Taylor, K. W. (1974). J. Endocr. 62, I 37.

Hager, D., Georg, R. H., Leitner, J. W. \& Beck, P. (1972). Endocrinology 9r, 977.

Henschel, M. J. (1973). Br. J. Nutr. 30, 35I.

Kennedy, G. C., Pearce, W. A. \& Parrott, D. M. V. (1958). J. Endocr. 17, 158.

Kunitz, M. (1939). J. gen. Physiol. 22, 447.

Leake, R. E., Mayne, R. \& Barry, J. M. (I968). Biochim. biophys. Acta 157, 198.

Malaisse, W. J., Malaisse-Lagae, F., Picard, C. \& Flament-Durand J. (1969). Endocrinology, 84, 4I.

Mayston, P. D. \& Barrowman, J. A. (197I). Q. Jl exp. Physiol. 56, I I 3.

Moon, S. J. (1973). Studies on the cell kinetics of the intestinal epithelium of sheep. PhD Thesis, University of Áberdeen.

Rolls, B. A. (1975). Br. J. Nutr. 33, I.

Saudek, C. D., Finowski, M. \& Knopp, R. H. (1975). J. clin. Invest. 55, I 80.

Schwenk, E. \& Joachim, E. (196I ). Proc. Soc. exp. Biol. Med. 108, 665.

Scow, R. O., Chernick, S. S. \& Brinley, M. S. (1964). Am. J. Physiol. 206, 796.

Smith, R. W. (1975). Biochim. biophys. Acta 411, 22.

Snook, J. T. (1974). Fedn Proc. Fedn Am. Socs exp. Biol. 33, 88.

Souders, H. (I955). Fedn Proc. Fedn Am. Socs exp. Biol. 14, 142.

Unger, R. H., Ketterner, H., Duprej, J. \& Eisentrant, A. M. (1967). J. clin. Invest. 46, 630.

Weekes, T. E. C. (1972). Observations on the metabolic role of the rumen epithelium. PhD Thesis, University of Aberdeen. 